\title{
Sprawozdanie z konferencji XX lat Instytutu Dziennikarstwa, Mediów i Komunikacji Społecznej UJ pt. „Wiedza. Komunikacja. Działanie”, Kraków, 25-26 października 2018 r.
}

Pod koniec października na Uniwersytecie Jagiellońskim w Krakowie odbyły się obrady jubileuszowej konferencji Instytutu Dziennikarstwa, Mediów i Komunikacji Społecznej Uniwersytetu Jagiellońskiego pt. „Wiedza. Komunikacja. Działanie”. Konferencję zorganizowano z okazji XX lat istnienia Instytutu Dziennikarstwa, Mediów i Komunikacji Społecznej UJ. Pierwsza, jubileuszowa, część konferencji obejmowała uroczystość oficjalną z udziałem JM Rektora UJ prof. dr. hab. Wojciecha Nowaka, Dziekana Wydziału Zarządzania i Komunikacji Społecznej prof. dr. hab. Piotra Jedynaka oraz zaproszonych gości, m.in. władz wydziałów i instytutów dziennikarstwa z innych polskich ośrodków naukowych. W mowie inauguracyjnej JM Rektor UJ wspomniał o rozwoju dyscypliny, interdyscyplinarności badań medioznawczych oraz życzył uczestnikom owocnych obrad. W dalszej części uroczystości głos zabrała dyrektor Instytutu Dziennikarstwa, Mediów i Komunikacji Społecznej UJ dr hab. Agnieszka Hess oraz prof. dr hab. Teresa Sasińska-Klas, inicjatorka powołania Międzynarodowej Szkoły Dziennikarskiej UJ oraz wieloletnia dyrektor Instytutu. Po części jubileuszowej prelegentów zaproszono na nowoczesny kampus Wydziału Zarządzania i Komunikacji Społecznej Uniwersytetu Jagiellońskiego, gdzie odbyły się dalsze uroczystości. Część naukową zainaugurował panel pt. „Czy prasa przetrwa? Od prasoznawstwa do medioznawstwa" moderowany

${ }^{1}$ Dr Jarosław Kinal, Instytut Socjologii Uniwersytetu Rzeszowskiego, al. T. Rejtana 16C, 35-959 Rzeszów, e-mail: jaroslawkinal@ gmail.com 
przez dr hab. Małgorzatę Lisowską-Magdziarz, prof. UJ, w którym udział wzięli prof. dr hab. Janusz Adamowski z Uniwersytetu Jagiellońskiego, prof. Iwona Hoffman z Uniwersytetu Marii Curie-Skłodowskiej w Lublinie, dr hab. Michał Drożdż, prof. UPJPII w Krakowie, red. Michał Kuźmiński, zastępca redaktora naczelnego „Tygodnika Powszechnego", oraz red. Marzena Suchan, szefowa działu Wiadomości portalu Onet.pl. Dyskutanci wskazali na zmianę formy wydawniczej prasy $\mathrm{z}$ druku na treść cyfrową oraz prognozowali, że papierowe wersje gazet będą miały charakter elitarny. Uczestnicy panelu wskazali jednak na synergię wydania papierowego oraz cyfrowego. Po zakończeniu panelu dyskusyjnego odbyło się uroczyste nadanie imienia zmarłego w 2018 r. prof. dr. hab. Walerego Pisarka głównej auli Instytutu Dziennikarstwa, Mediów i Komunikacji Społecznej UJ. W dalszej części konferencji obrady podzielono na pięć sesji tematycznych: media i sfera publiczna; media, polityka i społeczeństwo obywatelskie; media i kultura; język i obraz w mediach; transformacja mediów (historia, system, zarządzanie). Każdy panel był moderowany przez uznany w środowisku medioznawczym autorytet, a po wysłuchaniu wszystkich wystąpień w danym panelu głos zabierał dyskutant, który podsumowywał wystąpienia oraz inicjował zadawanie pytań do każdego z prelegentów.

Pierwsza sesja tematyczna pt. „Media i sfera publiczna” składała się z trzech paneli dyskusyjnych: media a opinia publiczna, media a europejska sfera publiczna oraz rola mediów i dziennikarzy w kształtowaniu sfery publicznej. Zawierała wystąpienia badaczy zajmujących się problematyką znaczenia mediów w procesie kształtowania opinii publicznej, a także roli mediów i dziennikarzy w tworzeniu i przekształcaniu sfery publicznej, zarówno w ujęciu lokalnym, jak i światowym. W sesji zaprezentowano 15 referatów. Wśród prelegentów w wystąpieniu pt. Dziennikarstwo obywatelskie jako element sfery publicznej wyniki swoich badań zaprezentował dr hab. Wojciech Furman, prof. UR, zaś referat pt. Kto mówi wygłosił dr Krzysztof Piróg z Instytutu Socjologii Wydziatu Socjologiczno-Historycznego UR.

Druga sesja tematyczna zatytułowana „Media, polityka i społeczeństwo obywatelskie", której motywem przewodnim była złożoność relacji mediów i polityki w kontekście społeczeństwa obywatelskiego, składała się z czterech paneli tematycznych. Panel „Dialog obywatelski” poświęcony został społecznemu wykorzystaniu, charakterystyce oraz skuteczności mediów i praktyk komunikowania publicznego w tworzeniu, realizacji i redefinicji dialogu obywatelskiego w różnych kontekstach poli- 
tycznych, ekonomicznych oraz kulturowych. Drugi panel „Komunikacja, mediatyzacja, wybory" dotyczył przemian w komunikacji politycznej towarzyszących wyborom, w szczególności tych, które wynikają z rewolucji w świecie mediów. Trzeci panel obejmował wystąpienia dotyczące populizmu zarówno jako stylu komunikacji, jak i doktryny w ujęciu krajowym i zagranicznym. Czwarty panel poświęcono problematyce komunikacji politycznej w aspekcie wyborów. W sesji zaprezentowano 20 referatów.

Trzecia sesja zatytułowana „Media i kultura” zawierał 20 wystąpień pogrupowanych w cztery panele tematyczne: „Literatura a dziennikarstwo”, „Radio i telewizja dziš”, „Nowe media, konwergencja i kultura partycypacji” oraz „Media w komunikacji interkulturowej”. W sesji pierwszej referat pt. Preferencje i rytuaty odbioru telewizji tradycyjnej i interaktywnej (webtv) wśród podkarpackich licealistów wygłosił dr Jarosław Kinal z Wydziału Socjologiczno-Historycznego UR.

Czwarta sesja tematyczna pt. „Język i obraz w mediach” została podzielona na trzy panele: „Język, tekst, dyskurs w komunikowaniu publicznym", w którym zaprezentowano wyniki prac badaczy komunikacji językowej w dyskursach publicznych (np. medialnej metaforyki, leksyki, stylów językowych), a także wyniki badań językowych i medialnych obrazów świata, ze szczególnym uwzględnieniem dynamicznych kontekstów kulturowych, społecznych, politycznych ponowoczesnych strategii komunikacyjnych w epoce powszechnej mediatyzacji i medializacji rzeczywistości. Drugi panel sekcji pt. „Komunikacja wizualna w mediach" został poświęcony badaniom mediów wizualnych w perspektywie kulturowej, etycznej oraz technicznej. W panelu zaprezentowano wyniki badań specjalistów zajmujących się sferą medialnej ikonosfery, a także autorów innowacyjnych metod $\mathrm{i}$ technik w zakresie analiz i interpretacji obrazu i jego funkcji. Trzeci panel pt. „Multimedialne i wielomodalne strumienie przekazów jako ustrukturyzowane «opowieści o świecie» (trans)medialne narracje o rzeczywistości" poświęcony został transmedialnym narracjom o świecie. Szczególnie istotnym obszarem tego panelu był aksjologiczny wymiar medialnych narracji, a zwłaszcza językowe i pozajęzykowe wykładniki wartościowania we współczesnych środkach przekazu odnoszącego się do sfery politycznej, społecznej, ekonomicznej i kulturowej. Czwarty panel pt. „Narracje, dyskursy o świecie w mediach" został poświęcony kwestiom obecności medialnej oraz wyspecjalizowanej roli dziennikarzy specjalistycznych. W opisywanej sesji tematycznej zaprezentowano łącznie 21 referatów.

Piąta sesja tematyczna zatytułowana „Transformacje mediów (historia, system, zarządzanie)" zawierała wystąpienia obejmujące tematykę 
zmian w obszarze funkcjonowania mediów, jakie towarzyszyły transformacji społecznej i politycznej Polski po $1989 \mathrm{r}$.

W wydarzeniu wzięło aktywny udział pięciu reprezentantów Uniwersytetu Rzeszowskiego: dr. hab. Wojciech Furman, prof. UR, dr Krzysztof Piróg oraz dr Jarosław Kinal z Wydziału Socjologiczno-Historycznego UR, dr Jakub Czopek z Wydziału Pedagogicznego UR oraz dr Marta Rzepecka z Uniwersyteckiego Centrum Języków Obcych.

Cennym elementem konferencji była ożywiona dyskusja naukowa, w tym dotycząca współpracy interdyscyplinarnej w zakresie organizacji i realizacji wspólnych badań. Trwałym śladem konferencyjnych prelekcji oraz dyskusji będą publikacje w czasopismach medioznawczych: „Zeszyty Prasoznawcze” oraz „Com.press”. 